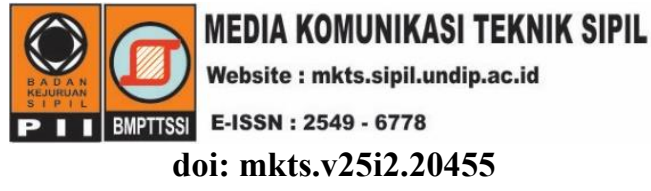

\title{
Analisis Faktor-faktor yang Mempengaruhi Penentuan Jenis Pemeliharaan Embung Irigasi
}

\author{
"Melchior Bria, Sutirto, Anastasia H. Muda \\ Jurusan Teknik Sipil Politeknik Negeri Kupang \\ ${ }^{*}$ melchibria@yahoo.co.id
}

Received: 27 September 2018 Revised: 25 November 2019 Accepted: 29 November 2019

\begin{abstract}
Maintenance of good and sustainable irrigation ponds have an impact on ensuring the sustainability of the irrigation system. For this reason, it is necessary to develop a reservoir maintenance model based on multicriteria analysis relating to the type of maintenance. The method used Structural Equation Model (SEM) with the WarpPLS approach. The criteria used Structural Stability, Economy / Finance, and Physical \& Environmental. The findings obtained variable structural stability has a very significant effect on the maintenance of irrigation ponds $(r<0.01$ and $\beta=0.73)$. Economic / financial variables have not significant effect on reservoir maintenance where $r=0.3$ and $\beta=0.03$. Physical and environmental variables also did not directly influence the maintenance of ponds with $r=0.29$ and $\beta=0.03$. However, the physical \& environmental variables significantly influenced structural stability with $r<0.01$ and $\beta=0.32$. Physical and environmental variables also significantly influenced economic/financial where $r<0.01$, and $\beta=0.45$. This finding supported various previous studies for structural stability variable but different for economic/financial variables that did not significantly affect by the determination of reservoir types.
\end{abstract}

Keywords: Small dam, irrigation, maintenance

\begin{abstract}
Abstrak
Pemeliharaan embung irigasi yang baik dan berkesinambungan berdampak pada terjaminnya keberlanjutan sistem irigasi. Untuk itu, perlu kiranya dikembangkan model pemeliharaan embung berdasarkan analisis multikriteria yang berkaitan dengan jenis pemeliharaan. Metode yang digunakan adalah Structural Equation Model (SEM) dengan pendekatan WarpPLS. Kriteria yang dipakai adalah Stabilitas Struktur, Ekonomi/Finansial dan Fisik \& Lingkungan. Hasil analisa menunjukkan bahwa variabel stabilitas struktur berpengaruh sangat signifikan terhadap pemeliharaan embung irigasi $(\rho<0,01$ dan $\beta=0,73)$. Variabel ekonomi/finansial tidak berpengaruh siginifikan pada pemeliharaan embung dimana $\rho=0,3$ dan $\beta=0,03$. Variabel fisik \& lingkungan juga tidak berpengaruh langsung terhadap pemeliharaan embung dengan $\rho=$ 0,29 dan $\beta=0,03$. Namun demikian variabel fisik \& lingkungan siginifikan berpengruh terhadap stabilitas struktur dengan $\rho<0,01$ dan $\beta=0,32$. Variabel fisik dan lingkungan juga signifikan berpengaruh terhadap ekonomi/finansial dimana $\rho<0,01$, dan $\beta=0,45$. Temuan ini, mendukung berbagai studi terdahulu untuk variabel stabilitas struktur akan tetapi berbeda untuk variabel ekonomi/finansial yang tidak siginifikan berpengaruh terhadap penentuan jenis pemeliharaan embung.
\end{abstract}

Kata kunci: Embung, irigasi, pemeliharaan

\section{Pendahuluan}

Embung irigasi dapat disebut juga bendungan kecil (small dams) adalah suatu bangunan irigasi yang memanfaatkan daerah cekungan kemudian pada daerah tersebut dibangun suatu tanggul atau disebut tubuh bendungan agar air yang mengalir di permukaan atau yang turun ke tanah dapat ditampung seoptimal mungkin dan digunakan pada saat selesai musim hujan untuk mengairi lahan pertanian. Embung merupakan teknik pemanenan air, dimana ketersediaan air dari embung pada musim kemarau sangat bergantung pada besarnya evaporasi, perkolasi dan aliran samping, dan dianggap sebagai kehilangan air (Hermantoro, 2011). Pola pemanenan air ini selain untuk menjamin ketersediaan air juga dapat 
memperlambat laju aliran permukaan dan meresapkannya ke tanah (Direktorat Jenderal Prasarana dan Sarana Pertanian, 2019). Sedangkan, bendungan (dams) adalah bangunan yang dibangun untuk memotong limpasan dan membentuk waduk (reservoir) dan air yang ditampung dapat difungsikan sebagai konservasi dan pengendalian banjir (Umaru et al. 2010).

Uraian di atas menunjukkan bahwa embung irigasi yang dikategorikan sebagai bendungan kecil, memiliki manfaat besar baik untuk memenuhi kebutuhan air akan irigasi maupun sebagai pengendali banjir. Untuk menjaga embung tetap dapat berfungsi, maka diperlukan program pemeliharaan embung yang sistematis dan terarah.

Permasalahannya, pengelolaan embung pada umumnya di Indonesia terkendala minimnya anggaran pemeliharaan, termasuk di wilayah Timor, NTT. Embung di NTT umumnya mengalami penurunan fungsi disebabkan oleh beberapa faktor, antara lain adanya komponen embung yang rusak dan kegiatan operasional dan pemeliharaan yang tidak dilakukan dengan benar (Meluk et.al., 2015). Selain itu, permasalahan yang sering muncul dalam menangani bendungan kecil adalah kurangnya perbaikan dan pemeliharaan yang disebabkan kurangnya sumber daya yang ada (Mufute, 2007), sementara sumber daya merupakan salah satu faktor yang penting dalam pemeliharaan irigasi (Amin et al. 2016).

Pada dasarnya, pemeliharaan bangunan utama dari suatu sistem irigasi, merupakan salah satu kegiatan penting untuk menjamin keberlanjutan irigasi pada suatu satuan wilayah tertentu. Pemeliharaan bangunan irigasi adalah upaya menjaga dan mengamankan jaringan irigasi agar selalu dapat berfungsi dengan baik guna memperlancar pelaksanaan operasi dan mempertahankan kelestariannya yang meliputi pengamanan jaringan irigasi, pemeliharaan rutin, pemeliharaan berkala dan perbaikan (Peraturan Menteri Pekerjaan Umum, 2015).

Atas dasar itu maka usaha pemeliharaan dan penilaian terhadap daerah-daerah irigasi yang sudah ada harus ditingkatkan kedepannya untuk mendapatkan hasil kinerja yang lebih baik dan kinerja yang optimal (Sayekti et al. 2012). Kinerja sistem irigasi ini dipengaruhi oleh beberapa faktor antar lain pelayanan irigasi, aspek kelembagaan (P3A), sumber daya manusia dan modernisasi operasi dan pemeliharaan (Mulyadi et al. 2014). Namun demikian, operasi dan pemeliharaan bangunan itu tidaklah mudah dan apabila bangunan tidak dipelihara dengan baik dan benar, maka akan membutuhkan biaya rehabilitasi yang lebih besar
(Heryant et al. 2014). Untuk itu diperlukan rencana program pemeliharaan yang terarah, sistematis dan menyeluruh.

Perencanaan program pemeliharaan ini sangat dipengaruhi oleh beberapa faktor. Salah satu yang terpenting adalah struktur bendung. Hal ini karena dalam banyak kasus kegagalan bisa dicegah jika struktur dipelihara dengan baik. Apalagi bendungan sejatinya rentan terhadap gaya gempa, sehingga menjaga bendungan terus menerus secara baik sangat diperlukan (Wieland, 2016). Penentuan jenis pemeliharaan juga dilakukan berdasarkan penilaian kondisi dan fungsi bangunan irigasi sehingga dapat dibuat urutan prioritas pemeliharaannya (Wibowo et al. 2018). Sementara itu, penilaian tidak cukup pada keseluruhan bangunan utama, tetapi perlu ditambah bangunan pelengkap dan instrumen serta perlu pula memperhatikan aspek ekonomi (Heryant et al. 2014).

Selain faktor struktural, perlu pula memperhatikan lingkungan sekitar embung. Sebagai contoh, embung-embung di Kabupaten Belu, dari aspek lingkungan terdapat vegetasi (savana, padang rumput, semak belukar, asosiasi pohon-semak dan rumput), dan sangat khas menunjukkan keberadaannya di wilayah Timor (Widiyono, 2011).

Adanya pohon, gundukan rayap dan dalam beberapa kasus adanya jalur ternak di tanggul bendungan merupakan manifestasi pemeliharaan yang buruk yang jika tidak dikendalikan akan mengancam kelestarian embung (Nugroho \& Suripin, 2013; Nyoni, 2013). Adanya vegetasi serta biaya konstruksi maupun pemeliharaan merupakan faktor-faktor yang berpengaruh dalam pembangunan embung (Anjasmoro et al. 2015).

Dari aspek teknis pengelolaan, permasalahan terkait manajemen operasi irigasi yang kurang tepat penerapannya dapat menimbulkan konflik. Apalagi dengan terbatasnya biaya operasi dan pemeliharaan sehingga fungsi jaringan cepat menurun (Joubert, \& Prihantoko, 2015). Dengan demikian dapat diidentifikasi faktor-faktor yang mempengaruhi penyusunan program pemeliharaan embung antara lain struktur bendungan/embung, fisik dan lingkungan, dan ekonomi.

Pada studi sebelumnya ketiga atau kriteria di atas diidentifikasi berpengaruh dalam program pemeliharaan embung irigasi dan ditambah dengan aspek kebijakan pemerintah serta aspek sosial budaya (Bria et al. 2017). Secara lengkap kriteriakriteria tersebut ditampilkan dalam Tabel 1. Hasil uji kriteria dan subkriteria pada Tabel 1 tersebut dilakukan pada wilayah layanan Embung Haliwen dan Haekrit di Atambua Kabupaten Belu. 
Tabel 1. Kriteria pemeliharaan embung irigasi

\begin{tabular}{|c|c|}
\hline Kriteria & Subkriteria \\
\hline $\begin{array}{l}\text { A. } \begin{array}{l}\text { Stabilitas } \\
\text { struktur }\end{array}\end{array}$ & $\begin{array}{l}\text { A1. Tubuh bendungan } \\
\text { A2. Kolam embung } \\
\text { A3. Pelimpah (spillway) } \\
\text { A4. Jaringan distribusi air } \\
\text { A5. Bangunan bantu }\end{array}$ \\
\hline $\begin{array}{ll}\text { B. } & \text { Fisik dan } \\
& \text { lingkungan }\end{array}$ & $\begin{array}{l}\text { B1. Perubahan bentangan alam } \\
\text { B2. Curah hujan dan } \\
\text { evapotranspirasi } \\
\text { B3. Struktur tanah sekitar } \\
\text { embung } \\
\text { B4. Tanaman pengganggu } \\
\text { sekitar embung }\end{array}$ \\
\hline $\begin{array}{l}\text { C. Ekonomi / } \\
\text { finansial }\end{array}$ & $\begin{array}{l}\text { C1. Hasil produksi pertanian } \\
\text { C2. Nilai manfaat ekonomi } \\
\text { embung } \\
\text { C3. Dana investasi }\end{array}$ \\
\hline D. $\begin{array}{l}\text { Kebijakan } \\
\text { pemerintah }\end{array}$ & $\begin{array}{l}\text { D1. Rencana tata ruang } \\
\text { wilayah } \\
\text { D2. Penyediaan anggaran } \\
\text { pemeliharaan } \\
\text { D3. Water management } \\
\text { D4. Aspek kelembagaan } \\
\text { (organisasi) }\end{array}$ \\
\hline $\begin{array}{ll}\text { E. } & \begin{array}{l}\text { Sosial } \\
\text { budaya }\end{array}\end{array}$ & $\begin{array}{l}\text { E1. Partisipasi masyarakat } \\
\text { E2. Kearifan lokal/hukum } \\
\text { adat } \\
\text { E3. Pengembangan } \\
\text { kepariwisataan }\end{array}$ \\
\hline
\end{tabular}

Namun demikian, menarik untuk lebih mendalami seberapa signifikan tingkat pengaruh dari kriteriakriteria tersebut di atas dalam penentuan jenis pemeliharaan embung? Tulisan berikut ini membahas tingkat pengaruh atau hubungan dari masing-masing faktor tersebut terhadap penentuan jenis pemeliharaan embung irigasi dan hubungan pengaruh antar faktor tersebut dalam membentuk opini terhadap penentuan jenis pemeliharaan embung.

Dalam studi kasus ini kriteria yang digunakan adalah struktur embung, fisik/lingkungan dan aspek ekonomi/finansial. Lokasi studi adalah wilayah layanan embung irigasi Haliwen dan Haekrit di Atambua Kabupaten Belu.

\section{Embung Haliwen}

Secara geografis terletak pada $09^{0} 04^{\prime} 59,3^{\prime \prime} \mathrm{LS}$ dan $124^{0} 55^{\prime}$ 57,8" BT. dengan batas-batas wilayah yaitu, sebelah utara berbatasan dengan Selat Ombai, sebelah selatan berbatasan dengan Kota Atambua, sebelah timur berbatasan dengan Kecamatan Tasifeto Timur, sebelah barat berbatasan dengan Kabupaten TTU. Secara administratif Embung
Haliwen terletak di Kecamatan Tasifeto TimurBelu dan berada pada ketinggian $340 \mathrm{~m}$ di atas permukaan laut, memiliki dua inlet anak sungai utama yang mengalir dari arah Selatan, dan empat inlet anak sungai berukuran kecil, masing-masing tiga anak sungai dari arah timur dan 1 anak dari arah barat dengan luas daerah aliran sungai (DAS) 7,5 Ha (Balai Wilayah Sungai NT II, 2015).

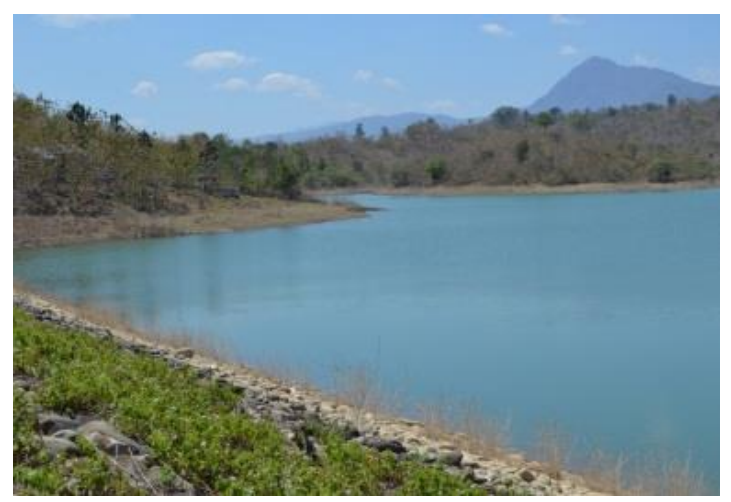

Gambar 1. Kolam tampungan Embung Haliwen

Kondisi Embung Haliwen cukup baik dan berfungsi. Gambar 1 memperlihatkan Kolam Embung Haliwen secara visual tampak baik dimana pada musim kemarau masih terdapat air yang tertampung, meskipun terjadi penurunan air yang siginifikan kurang lebih sekitar empat meter dari tampungan air normal dimana dari hasil pengukuran diperoleh elevasi muka air normal +336 m sedangkan elevasi muka air saat dilakukan survey adalah $+332 \mathrm{~m}$.

Kondisi saluran irigasi berfungsi baik, tidak terlihat adanya kerusakan yang cukup berarti. Pintu-pintu air masih dapat berfungsi, roda gigi pada pintu juga masih berfungsi. Terdapat pula jaringan pipa transmisi yang digunakan untuk mengalirkan air hasil olahan sebagai air bersih untuk masyarakat Kota Atambua dan sekitarnya. Bangunan sadap dan bangunan bagi juga terlihat baik. Pada beberapa ruas saluran terjadi retak-retak dan juga dinding saluran mengalami keruntuhan.

Secara teknis embung ini memiliki panjang tanggul $130 \mathrm{~m}$ dan tinggi $20 \mathrm{~m}$. Volume tampung embung adalah $1.860 .000 \mathrm{~m}^{3}$ dengan luas genangan mencapai $28 \mathrm{~m}^{2}$, melayani lahan irigasi $300 \mathrm{Ha}$ dan untuk air baku sebesar 10 liter/detik. Komoditi utama hasil pertanian adalah padi dengan pola tanam dua kali dalam satu tahun, yaitu saat musim hujan dan kemarau (Balai Wilayah Sungai NT II, 2015). Permasalahan yang dijumpai selain penurunan debit air pada musim kemarau juga pada tubuh bendungan dijumpai banyak tumbuhan liar, dan semak-semak, juga adanya sedimentasi di sekitar pelimpah. 


\section{Embung Haekrit}

Embung Irigasi Haekrit terletak di Desa Manleten, Kecamatan Tasifeto Timur, Kabupaten Belu, berjarak sekitar $\pm 5 \mathrm{~km}$ dari kota Atambua atau \pm $295 \mathrm{~km}$ dari Kupang dan berada pada posisi Latitude (S): $09^{0} 08$ ' 08.81" dan Longitude (E): $124^{0} 35^{\prime}$ 07.73". Maksud pembangunan Embung Irigasi Haekrit adalah guna pengembangan sarana dan prasarana sumber air untuk memenuhi kebutuhan air bagi masyarakat di Kabupaten Belu khususnya Kecamatan Tasifeto Timur, Desa Manleten.

Sedangkan tujuan dibangunnya Embung Irigasi Haekrit adalah untuk mengairi areal irigasi potensial seluas $300 \mathrm{Ha}$, dengan intensitas tanam sebesar 250\%, sebagai suplesi air baku sebesar 30 liter/detik, untuk desa sekitarnya dan sebagian kota Atambua dan konservasi sumber daya air dan lahan (Balai Wilayah Sungai NT II, 2015).

Berdasarkan hasil pengamatan, ambang mercu pelimpah berada pada elevasi $+374 \mathrm{~m}$, lantai pengarah di udik pelimpah terletak pada elevasi +364 m dengan lebar mercu, bangunan peluncur dan ruang olak sekitar 8,5 meter. Bangunan pelimpah tidak berpintu yang terdiri dari mercu pelimpah, saluran pengarah, saluran peluncur dan bangunan pemecah energi dibangun di bukit tumpuan kiri.

Kolam Embung Haekrit secara visual tampak baik dimana pada musim kemarau masih terdapat air yang tertampung, meskipun terjadi penurunan air yang siginifikan kurang lebih sekitar 4 meter dari tampungan air normal di mana dari hasil pengukuran diperoleh elevasi muka air normal +376 m sedangkan elevasi muka air saat dilakukan survey adalah $+372 \mathrm{~m}$.

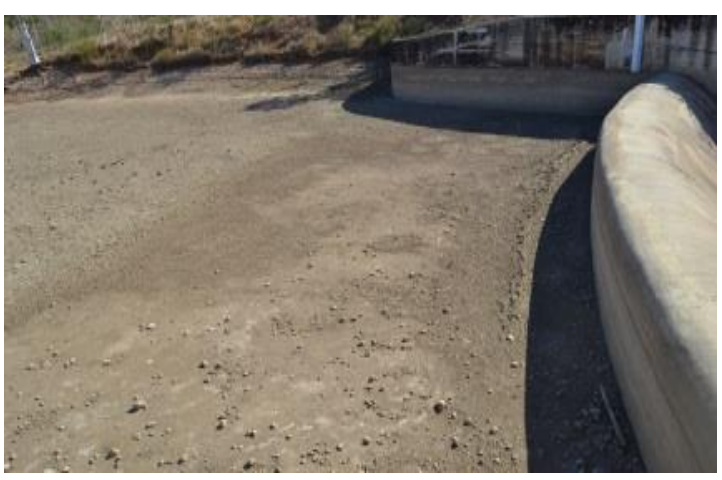

Gambar 2. Sedimentasi di sekitar pelimpah

Gambar 2 memperlihatkan secara jelas, penumpukan sedimentasi sekitar pelimpah sehingga mengurangi volume tampungan dan dapat mengganggu stabilitas pelimpah.
Saluran irigasi yang berfungsi mengalirkan air dari embung ke lahan pertanian masyarakat Desa Manleten terlihat masih berfungsi.

Namun demikian, pada beberapa ruas saluran terjadi retak-retak dan juga dinding saluran mengalami keruntuhan. Pintu-pintu air masih dapat berfungsi, roda gigi pada pintu juga masih berfungsi. Terdapat pula jaringan pipa transmisi yang digunakan untuk mengalirkan air hasil olahan sebagai air bersih untuk masyarakat Kota Atambua dan sekitarnya. Bangunan sadap dan bangunan bagi juga terlihat baik. Umumnya jenis tanaman yang diusahakan adalah jenis tanaman palawija termasuk sayur-sayuran. Desa Manleten ini dikenal sebagai daerah penghasil sayur-sayuran terbesar di Wilayah Atambua dan sekitarnya.

\section{Metode Penelitian}

Penelitian ini merupakan penelitian survey, dimana data diperoleh dari hasil pengisian kuesioner oleh responden. Data yang telah terkumpul kemudian dianalisis menggunakan Structural Equation Model (SEM) dengan pendekatan WarpPLS.

SEM adalah salah satu analisis multivariat dan merupakan metode penelitian kuantitatif dan hingga saat ini telah diterapkan pada berbagai bidang kajian baik sosial, ekonomi, teknik, pertanian, psikologi, dan bidang lainnya. Dalam SEM, variabel yang digunakan adalah variabel laten yang pengukurannya dilakukan secara tidak langsung melalui indikator sebagai variabel yang diamati (Kock, 2019).

\section{Merancang inner dan outer model}

Tahapan awal dalam model SEM WarpPLS adalah merancang inner model dan outer model. Inner model akan menunjukkan posisi hubungan antar variabel dalam model. Sedangkan outer model akan menujukkan sifat dari indikator yang membentuk variabel apakah bersifat reflektif ataukah formatif. Untuk itu maka terlebih dahulu diidentifikasi variabel laten yang diamati beserta indikatornya.

Dalam studi ini variabel yang digunakan yaitu stabilitas struktur, ekonomi/finansial, dan variabel fisik \& lingkungan sebagaimana yang diuraikan di Pendahuluan. Sedangkan variabel yang akan dicari hubungannya dengan ketiga variabel di atas adalah pemeliharaan embung. Indikator dari tiap-tiap variabel diperoleh dari penelitian terdahulu dan berdasarkan peraturan perundangan yang berlaku, serta kajian teoritis. Variabel dan indikator yang digunakan adalah seperti pada Tabel 2. 
Tabel 2. Variabel dan indikator

\begin{tabular}{cll}
\hline No & \multicolumn{1}{c}{ Variabel } & \multicolumn{1}{c}{ Indikator } \\
\hline 1 & Pemeliharaan embung $-\mathrm{PE}\left(\mathrm{Y}_{1}\right)$ & Pemeliharaan rutin $\left(\mathrm{Y}_{1.1}\right)$ \\
& & Pemeliharaan berkala $\left(\mathrm{Y}_{1.2}\right)$ \\
& & Perbaikan $\left(\mathrm{Y}_{1.3}\right)$ \\
\hline 2 & Stabilitas struktur $-\mathrm{SS}\left(\mathrm{Y}_{2}\right)$ & Tubuh bendungan $\left(\mathrm{Y}_{2.1}\right)$ \\
& & Kolam embung $\left(\mathrm{Y}_{2.2}\right)$ \\
& & Spillway $\left(\mathrm{Y}_{2.3}\right)$ \\
& & Jaringan distribusi $\left(\mathrm{Y}_{2.4}\right)$ \\
& & Bangunan bantu $\left(\mathrm{Y}_{2.5}\right)$ \\
\hline 3 & Ekonomi/finansial $-\mathrm{E} / \mathrm{F}\left(\mathrm{Y}_{3}\right)$ & Hasil produksi pertanian $\left(\mathrm{Y}_{3.1}\right)$ \\
& & Nilai manfaat $\left(\mathrm{Y}_{3.2}\right)$ \\
& & Dana investasi $\left(\mathrm{Y}_{3.3}\right)$ \\
\hline 4 & Fisik \& lingkungan $-\mathrm{FL}(\mathrm{X})$ & Perubahan bentangan alam $\left(\mathrm{X}_{1}\right)$ \\
& & Curah hujan dan evapotranspirasi $\left(\mathrm{X}_{2}\right)$ \\
& & Struktur tanah sekitar embung $\left(\mathrm{X}_{3}\right)$ \\
& & Tanaman pengganggu sekitar embung $\left(\mathrm{X}_{.4}\right)$ \\
\hline
\end{tabular}

Kerangka konseptual pada Gambar 1 sebagai pendekatan untuk menunjukkan keterkaitan antar variabel sebagai dasar merumuskan hipotesis. Pada variabel $Y_{1}, Y_{2}$ dan $X$, (lihat Tabel 2) model indikatornya adalah bersifat formatif karena indikator-indikator tersebut adalah yang membentuk variabel. Pada variabel ekonomi/finansial $\left(\mathrm{Y}_{3}\right)$, indikator bersifat reflektif karena indikator yang ada mencerminkan variabel yang terbentuk sehingga dapat dikatakan bahwa perubahan pada variabel akan menyebabkan perubahan pada indikator.

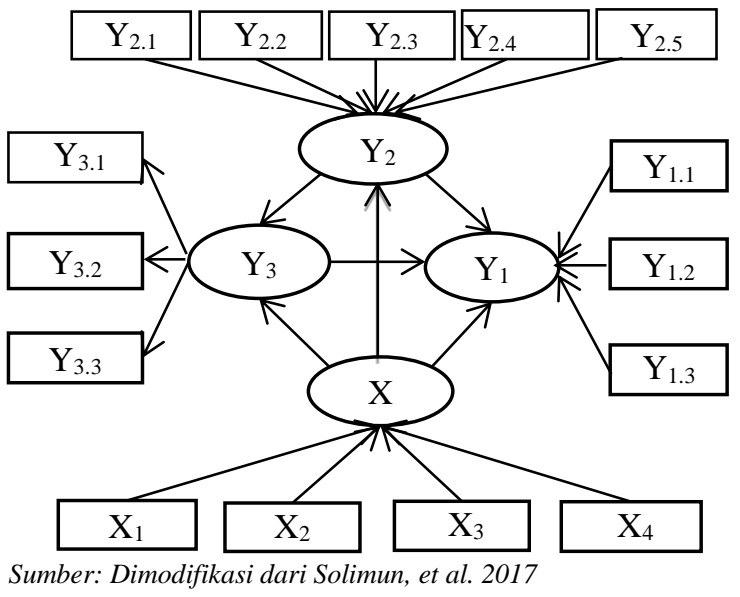

Gambar 3. Kerangka konseptual model hubungan antar variabel dan sifat indikator

Variabel $\mathrm{X}$ adalah variabel eksogen yaitu variabel yang nilainya ditentukan di luar model sedangkan variabel $Y$ adalah variabel yang nilainya ditentukan dalam model yaitu $\mathrm{Y}_{1}, \mathrm{Y}_{2}$ dan $\mathrm{Y}_{3}$, disebut sebagai variabel endogen. Dengan demikian maka dapat disusun suatu hipotesis hubungan antar variabel dalam Model Persamaan Struktural yang terdiri dari empat variabel dan 15 indikator (Tabel 2). Apabila ditulis dalam sistem persamaan sebagai berikut:

$$
\begin{aligned}
& Y_{1}=\beta_{01}+\beta_{1} X+\beta_{2} Y_{2}+\beta_{3} Y_{3}+\varepsilon_{1} \\
& Y_{2}=\beta_{02}+\beta_{2} X+\varepsilon_{2} \\
& Y_{3}=\beta_{03}+\beta_{3} X+\beta_{4} Y_{2}+\varepsilon_{1}
\end{aligned}
$$

Model seperti Gambar 3 melambangkan suatu hubungan pengaruh sebagai pendekatan untuk menggambarkan kondisi sesungguhnya yang selanjutnya akan diuji tingkat pengaruh atau hubungannya. Kerangka konseptual ini memperlihatkan pola hubungan antar variabel laten yang saling mepengaruhi. Maka hipotesis yang dibangun adalah:

(1) H0: Variabel stabilitas struktur $\left(\mathrm{Y}_{2}\right)$ tidak signifikan berpengaruh langsung terhadap pemeliharaan embung $\left(\mathrm{Y}_{1}\right)$. H1: Variabel stabilitas struktur signifikan berpengaruh langsung terhadap pemeliharaan embung.

(2) H0: Variabel ekonomi/finansial ( $\left.\mathrm{Y}_{3}\right)$ tidak signifikan berpengaruh langsung terhadap pemeliharaan embung $\left(\mathrm{Y}_{1}\right)$. $\mathrm{H} 1$ : Variabel ekonomi/finansial $\left(\mathrm{Y}_{3}\right)$ signifikan berpengaruh langsung terhadap pemeliharaan embung $\left(\mathrm{Y}_{1}\right)$.

(3) Ho: Variabel fisik \& lingkungan (X) tidak signifikan berpengaruh langsung terhadap pemeliharaan embung. H1: Variabel fisik \& lingkungan (X) signifikan berpengaruh langsung terhadap pemeliharaan embung.

(4) H0: Variabel fisik \& lingkungan (X) tidak signifikan berpengaruh langsung terhadap stabilitas struktur $\left(\mathrm{Y}_{2}\right) \mathrm{H} 1$ : Variabel fisik \& lingkungan $(\mathrm{X})$ signifikan berpengaruh langsung terhadap stabilitas struktur $\left(\mathrm{Y}_{2}\right)$.

(5) H0: Variabel fisik \& lingkungan (X) tidak signifikan berpengaruh langsung terhadap Ekonomi/Finansial $\left(\mathrm{Y}_{3}\right)$. H1: Variabel fisik \& lingkungan $(\mathrm{X})$ signifikan berpengaruh langsung terhadap ekonomi/finansial $\left(\mathrm{Y}_{3}\right)$. 
Untuk dapat menjawab hipotesis maka digunakan skala Likert sebagai cara mengukur variabel dan indikator, yaitu satu sampai dengan lima yang menyatakan tingkat hubungan tertentu antar variabel, yaitu 5 menyatakan tingkat kepentingan yang sangat tinggi, 4 menyatakan tingkat kepentingan yang tinggi, 3 menyatakan tingkat kepentingan yang cukup tinggi, 2 menyatakan tingkat kepentingan yang tidak tinggi, dan 1 menyatakan tingkat kepentingan yang sangat tidak tinggi. Responden berasal dari masyarakat penerima manfaat embung, petugas PPL, unit organisasi pemerintah, para pengambil keputusan dan ekspert.

\section{Uji model}

Uji model dalam SEM dilakukan untuk menentukan apakah model baik/cocok (fit) atau tidak. Parameter umum untuk menentukan suatu model baik ( $f i t)$ atau tidak adalah nilai APC (average path coefficient), ARS (average $R$-squared) dimana harus memenuhi nilai $\rho<0,05$ yang berarti signifikan. Selain itu juga berdasarkan nilai AVIF (average block VIF) dengan syarat $<=5$.

\section{Tabel 3. Model fit dan indikator kualitas}

\begin{tabular}{lll}
\hline \multicolumn{1}{c}{ Indikator } & \multicolumn{1}{c}{ Hasil } & \multicolumn{1}{c}{ Ideal } \\
\hline Average path coefficient & $\rho<0.001$ & $\rho<0,05$ \\
Average - squared & $\rho<0.001$ & $\mathrm{P}<0.05$ \\
Average adjusted $R$-squared & $\rho<0.001$ & $\mathrm{P}<0.05$ \\
Average block VIF & 1,150 & $<=5$ \\
Average full collinearity VIF & 1,839 & $<=5$ \\
Tenenhaus GoF small $>=0.1$, & 0,380 & $\mathrm{Bes}$ \\
medium $>=0.25$, large $>=$ & & \\
O.36 & & \\
Sympson's paradox ratio & 1,000 & 1 \\
R-squared contribution ratio & 1,000 & 1 \\
Statistical suppression ratio & 1,000 & $>=0,7$ \\
$\begin{array}{l}\text { Nonlinear bivariate causality } \\
\text { direction ratio }\end{array}$ & 1,000 & $>=0,7$ \\
\hline
\end{tabular}

Uji model selanjutnya adalah menentukan validitas instrumen yang menghasilkan model berupa validitas konvergen dan diskriminan. Validitas konvergen diukur dari nilai loadings factor (faktor muatan) $>0,5$ dan signifikan $(\rho<0,01)$ sedangkan validitas diskriminan ditentukan dari nilai loadings (muatan) harus lebih besar dari nilai cross loadings (muatan silang).

Uji reliabilitas dimaksudkan untuk mengukur seberapa besar indikator reliabel dalam membentuk variabel. Reliabilitas diukur dari koefisien composite reliability (reliabilitas komposit) lebih besar dari 0,6 dan nilai koefisien Cronbach's aplha sebesar 0,50 sampai dengan 0,60 dianggap sebagai nilai yang cukup untuk reliabilitas (Haribowo, 2017). Selain itu pula dapat diukur dari uji indicator weight (bobot indikator) dimana mempunyai nilai signifikan $<0,01$ dan parameter collinearity berupa VIF (variance inflation factor) $<5$ (Solimun et al. 2017)

Selanjutnya dilakukan pengujian hipotesis menggunakan Uji t sebagaimana yang ada dalam analisis WarpPLS, dengan metode resampling. Penentuan keputusan terhadap variabel yang berpengaruh didasarkan pada ketentuan bahwa jika $\rho$ value $<0,10$ (alpha 10\%) maka dapat dikatakan weakly significant (signifikan lemah). Selanjutnya, jika $\rho$ value $<0,05$ (alpha 5\%) maka variabel tersebut significant (signifikan) dan jika $\rho$ value $<0,01$ (alpha 1\%) maka variabel dinyatakan highly significant (sangat signifikan)

\section{Hasil dan Pembahasan}

\section{Uji indikasi fit}

Uji ini dimaksudkan untuk memeriksa apakah inner model yang dibangun dengan data yang ada terindikasi fit atau tidak dan dikenal dengan istilah goodness of fit test (uji kebaikan/kecocokan). Model dikatakan memenuhi kriteria baik (fit) jika nilai $\rho$ value APC dan ARS $<0,05$ dan AVIF $<5$. Berdasarkan hasil pada Tabel 3 maka model yang disusun telah memenuhi kriteria model fit dimana nilai $\rho$ value dari APC dan ARS <0,001 yang berarti siginifikan sedangkan nilai AVIF sebesar 1,150. Dari nilai $R$-squared yang mencapai 0,9 menunjukkan kekuatan model yang mendekati ideal=1. Demikian pula parameter-parameter lainnya juga sesuai dengan syarat yang ditetapkan sehingga model yang dibangun memenuhi syarat indikator fit.

\section{Uji Validitas dan Reliabilitas}

\section{Uji validitas}

Hasil uji validitas memperlihatkan nilai loadings dari masing-masing indikator dan cross loading untuk menentukan validitas instrumen yang digunakan dalam penelitian. Tabel 4 memperlihatkan hasil pengujian validitas dimana terlihat faktor muatan $>0,5$ dan $\rho$ value $<0,001$ maka variabel yang diuji dalam penelitian ini memenuhi validitas konvergen.

Namun demikian pada indikator Y24, Y31, dan X14 nilai faktor loadings $<0,5$ tetapi memiliki pengrauh yang signifikan sehingga indikatorindikator tersebut dapat dikatakan valid. Sedangkan validitas diskriminan diukur dari faktor loading $>$ cross loading. Sebagai contoh variabel $\mathrm{Y}_{1.1}$ loadings factor sebesar 0,822 >cross loading (0.137; -0.033; -0.039) sehingga dapat dikatakan memenuhi validitas diskriminan. Dengan demikian 
dari keseluruhan indikator terlihat bahwa nilai loadings factor >dari cross loadings.

\section{Tabel 4. Kombinasi loadings dan} cross loadings

\begin{tabular}{crrrrl}
\hline & $\mathbf{Y}_{\mathbf{1}}$ & $\mathbf{Y}_{\mathbf{2}}$ & \multicolumn{1}{c}{$\mathbf{Y}_{\mathbf{3}}$} & \multicolumn{1}{c}{$\mathbf{X}$} & pvalue \\
\hline $\mathrm{Y}_{11}$ & 0,822 & 0,137 & $-0,033$ & $-0,039$ & $<0,001$ \\
$\mathrm{Y}_{12}$ & 0,797 & $-0,119$ & $-0,050$ & 0,029 & $<0,001$ \\
$\mathrm{Y}_{13}$ & 0,571 & $-0,031$ & 0,117 & 0,016 & $<0,001$ \\
$\mathrm{Y}_{21}$ & $-0,406$ & 0,646 & $-0,240$ & 0,136 & $<0,001$ \\
$\mathrm{Y}_{22}$ & 0,810 & 0,709 & $-0,033$ & $-0,039$ & $<0,001$ \\
$\mathrm{Y}_{23}$ & 0,031 & 0,733 & $-0,064$ & 0,113 & $<0,001$ \\
$\mathrm{Y}_{24}$ & $-0,456$ & 0,362 & 0,126 & $-0,125$ & $<0,001$ \\
$\mathrm{Y}_{25}$ & $-0,336$ & 0,503 & 0,357 & $-0,195$ & $<0,001$ \\
$\mathrm{Y}_{31}$ & $-0,153$ & 0,192 & 0,376 & $-0,202$ & $<0,001$ \\
$\mathrm{Y}_{32}$ & 0,016 & $-0,053$ & 0,865 & 0,070 & $<0,001$ \\
$\mathrm{Y}_{33}$ & 0,053 & $-0,032$ & 0,836 & 0,019 & $<0,001$ \\
$\mathrm{X}_{1}$ & $-0,028$ & $-0,109$ & 0,596 & 0,635 & $<0,001$ \\
$\mathrm{X}_{2}$ & $-0,140$ & 0,156 & $-0,235$ & 0,558 & $<0,001$ \\
$\mathrm{X}_{3}$ & 0,142 & $-0,035$ & $-0,163$ & 0,796 & $<0,001$ \\
$\mathrm{X}_{4}$ & $-0,040$ & 0,023 & $-0,280$ & 0,420 & $<0,001$ \\
\hline
\end{tabular}

Tabel 5. Akar AVE dan koefisien korelasi

\begin{tabular}{ccccc}
\hline & $\mathbf{Y}_{\mathbf{1}}$ & $\mathbf{Y}_{\mathbf{2}}$ & $\mathbf{Y}_{\mathbf{3}}$ & $\mathbf{X}$ \\
\hline $\mathrm{Y}_{1}$ & 0,739 & 0,607 & 0,156 & 0,199 \\
$\mathrm{Y}_{2}$ & 0,607 & 0,726 & 0,343 & 0,303 \\
$\mathrm{Y}_{3}$ & 0,156 & 0,343 & 0,728 & 0,481 \\
$\mathrm{X}$ & 0,199 & 0,303 & 0,481 & 0,618 \\
\hline
\end{tabular}

Tabel 5 menunjukkan bahwa nilai akar AVE pada diagonal utama lebih besar dari korelasi terhadap variabel yang bersangkutan. Misal variabel $\mathrm{Y}_{1}$ nilai akar AVE 0,739 lebih besar dari 0,607, 0,156 dan 0,199 . Hasil ini menunjukkan bahwa variabel $\mathrm{Y}_{1}$ memenuhi validitas diskriminan. Demikian halnya, untuk variabel lainnya, nilai akar AVE lebih besar dari korelasi terhadap variabel lainnya.

\section{Uji Reliabilitas}

Selanjutnya untuk uji reliabilitas ditentukan berdasarkan nilai composite reliability. Jika nilai koefisien composite reliability $>0,7$ maka alat ukur dinyatakan memenuhi reliabilitas komposit. Gambar 4 mempelihatkan nilai koefisien composite reliability semuanya $>0,7$ dan Cronbach's alpha $>0,5$ sehingga memenuhi syarat reliabilitaskecuali variabel X, nilai Cronbach's alpha sebesar 4,39 kurang dari 0,5 .

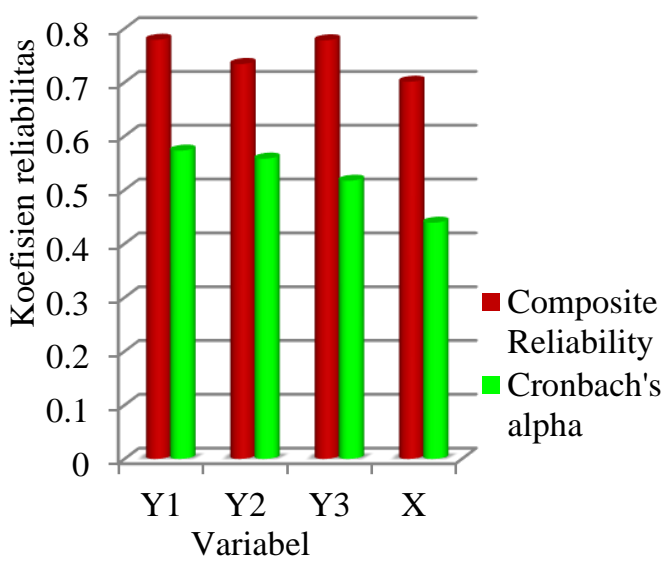

Gambar 4. Nilai composite reliability dan cronbach's alpha

Tabel 6. Nilai uji indicator weight untuk menentukan reliabilitas

\begin{tabular}{ccccccccccc}
\hline & $\mathbf{Y}_{\mathbf{1}}$ & $\mathbf{Y}_{\mathbf{2}}$ & $\mathbf{Y}_{\mathbf{3}}$ & $\mathbf{X}$ & Tipe & $\mathbf{S E}$ & $\boldsymbol{\rho}$ value & VIF & WLS & ES \\
\hline $\mathrm{Y}_{11}$ & 0,502 & 0 & 0 & 0 & Formatif & 0,064 & $<0,001$ & 1,339 & 1 & 0,412 \\
$\mathrm{Y}_{12}$ & 0,487 & 0 & 0 & 0 & Formatif & 0,064 & $<0,001$ & 1,309 & 1 & 0,388 \\
$\mathrm{Y}_{13}$ & 0,349 & 0 & 0 & 0 & Formatif & 0,066 & $<0,001$ & 1,076 & 1 & 0,199 \\
$\mathrm{Y}_{21}$ & 0 & 0,350 & 0 & 0 & Formatif & 0,066 & $<0,001$ & 1,198 & 1 & 0,226 \\
$\mathrm{Y}_{22}$ & 0 & 0,385 & 0 & 0 & Formatif & 0,066 & $<0,001$ & 1,242 & 1 & 0,273 \\
$\mathrm{Y}_{23}$ & 0 & 0,397 & 0 & 0 & Formatif & 0,066 & $<0,001$ & 1,331 & 1 & 0,291 \\
$\mathrm{Y}_{24}$ & 0 & 0,198 & 0 & 0 & Formatif & 0,068 & 0,002 & 1,144 & 1 & 0,072 \\
$\mathrm{Y}_{25}$ & 0 & 0,274 & 0 & 0 & Formatif & 0,067 & $<0,001$ & 1,178 & 1 & 0,138 \\
$\mathrm{Y}_{31}$ & 0 & 0 & 0,238 & 0 & Reflektif & 0,068 & $<0,001$ & 1,031 & 1 & 0,089 \\
$\mathrm{Y}_{32}$ & 0 & 0 & 0,544 & 0 & Reflektif & 0,064 & $<0,001$ & 1,426 & 1 & 0,471 \\
$\mathrm{Y}_{33}$ & 0 & 0 & 0,526 & 0 & Reflektif & 0,064 & $<0,001$ & 1,394 & 1 & 0,440 \\
$\mathrm{X}_{1}$ & 0 & 0 & 0 & 0,416 & Formatif & 0,065 & $<0,001$ & 1,113 & 1 & 0,264 \\
$\mathrm{X}_{2}$ & 0 & 0 & 0 & 0,366 & Formatif & 0,066 & $<0,001$ & 1,073 & 1 & 0,204 \\
$\mathrm{X}_{3}$ & 0 & 0 & 0 & 0,522 & Formatif & 0,064 & $<0,001$ & 1,209 & 1 & 0,416 \\
$\mathrm{X}_{4}$ & 0 & 0 & 0 & 0,276 & Formatif & 0,067 & $<0,001$ & 1,031 & 1 & 0,116 \\
\hline $\mathrm{C}_{4}$ & & 0 & 0 & 0 & & & & & &
\end{tabular}

Catatan: $\mathrm{P}$ values $<0,05$ dan VIFs $<2,5$ merupakan syarat untuk indikator formatif; VIF = indicator variance inflation factor; WLS = indicator weight-loading sign (-1 = Simpson's paradox in 1.v.); ES = indicator effect size. 
Namun demikian pada pemeriksaan besarnya pengaruh indikator (indicator weight), ditunjukkan dalam Tabel 6 terlihat bahwa variabel X signifikan berpengaruh dengan $\rho$ value $<0,001$ dan indikator VIF (variance inflation factor) $<5$ yang menunjukkan tidak terdapatnya gejala collinearlity sehingga dapat disimpulkan memenuhi syarat reliabilitas.

\section{Profil variabel}

Dalam mengamati profil variabel, loading faktor memberikan nilai yang jelas akan posisi atau tingkat kepentingan suatu variabel/indikator. Gambar 5 menunjukkan posisi kepentingan indikator dalam variabel. Terlihat bahwa indikator $\mathrm{Y}_{11}$ (pemeliharaan rutin) dalam variabel $\mathrm{Y}_{1}$ merupakan indikator yang penting karena nilai faktor loading cukup besar yaitu sebesar 0,822 dengan rata-rata skor 4,08 menunjukkan indikator tersebut penting dalam variabel $\mathrm{Y}_{1}$. Hal ini dapat dimengerti, karena dari gambaran umum Embung Haliwen dan Haekrit, tidak tampak adanya kerusakan yang serius tetapi perlu pemeliharaan rutin yang terencana untuk menjaga kondisi embung tetap berfungsi, seperti pembersihan semak-semak dan tumbuhan liar sekitar tubuh bendung, pemberian oli pada pintu air dan memperbaiki saluran distribusi air untuk tanaman.

Pada variabel $\mathrm{Y}_{2}$, loadings factor terbesar pada indikator $\mathrm{Y}_{23}$ (spillway) sebesar 0,733 dengan ratarata skor 3,79. Pada variabel $\mathrm{Y}_{3}$ loading factor terbesar ada pada indikator $\mathrm{Y}_{32}$ sebesar 0,865 dan pada variabel $X$, indikator $X_{.3}$ memiliki nilai loading factor sebesar 0,796.
Dari grafik dapat diamati pula, indikator-indikator yang loading factor di bawah 0,5 yaitu, $\mathrm{Y}_{24}, \mathrm{Y}_{31}$ dan $\mathrm{X}_{4}$, yang menunjukkan indikator-indikator tersebut lemah dalam membentuk atau mendukung variabel.

\section{Hasil uji hipotesis}

Gambar 6 memperlihatkan hasil uji hipotesis. Hasil model persamaan struktural menggambarkan hubungan antar masing-masing variabel yang saling berpengaruh. Terhadap variabel $\mathrm{Y}_{1}$, variabel $\mathrm{Y}_{2}$ berpengaruh siginifikan dimana nilai $\rho<0,01$ dengan koefisien jalur sebesar $\beta=0,73$, berarti menolak H0. Variabel Y3 tidak berpengaruh siginifikan pada Y1 dimana nilai $\rho=0,3>0,05$ dan koefisien jalur sebesar $\beta=0,03$, berarti terima $\mathrm{H} 0$. Koefisien jalur yang rendah ini menunjukkan pengaruh yang kecil dari variabel $\mathrm{Y}_{3}$ terhadap $\mathrm{Y}_{1}$. Dari hasil analisis juga terlihat bahwa variabel $\mathrm{Y}_{2}$ signifikan berpengaruh pada variabel $\mathrm{Y}_{3}$ dengan nilai $\rho<0,01$ dengan koefisien jalur sebesar $\beta=$ 0,22 .

\section{Pembahasan}

Sedangkan variabel $X$ dengan $\rho=0,29>0,10$, tidak siginifikan berpengaruh langsung terhadap variabel $\mathrm{Y}_{1}$ berarti terima $\mathrm{H} 0$. Namun demikian $\mathrm{X}$ siginifikan berpengruh terhadap variabel $Y_{2}$ dengan $\rho<0,01$ dan $\beta=0,32$, sehingga $Y_{2}$ sebagai variabel mediasi dapat diterima. Variabel $\mathrm{X}$ juga signifikan berpengaruh terhadap $Y_{3}$ dimana $\rho<0,01$, dan $\beta=0,45$. Hal ini menunjukkan bahwa kedudukan variabel $\mathrm{Y}_{3}$ sangat dipengaruhi oleh oleh variabel $\mathrm{Y}_{2}$ dan $\mathrm{X}$.

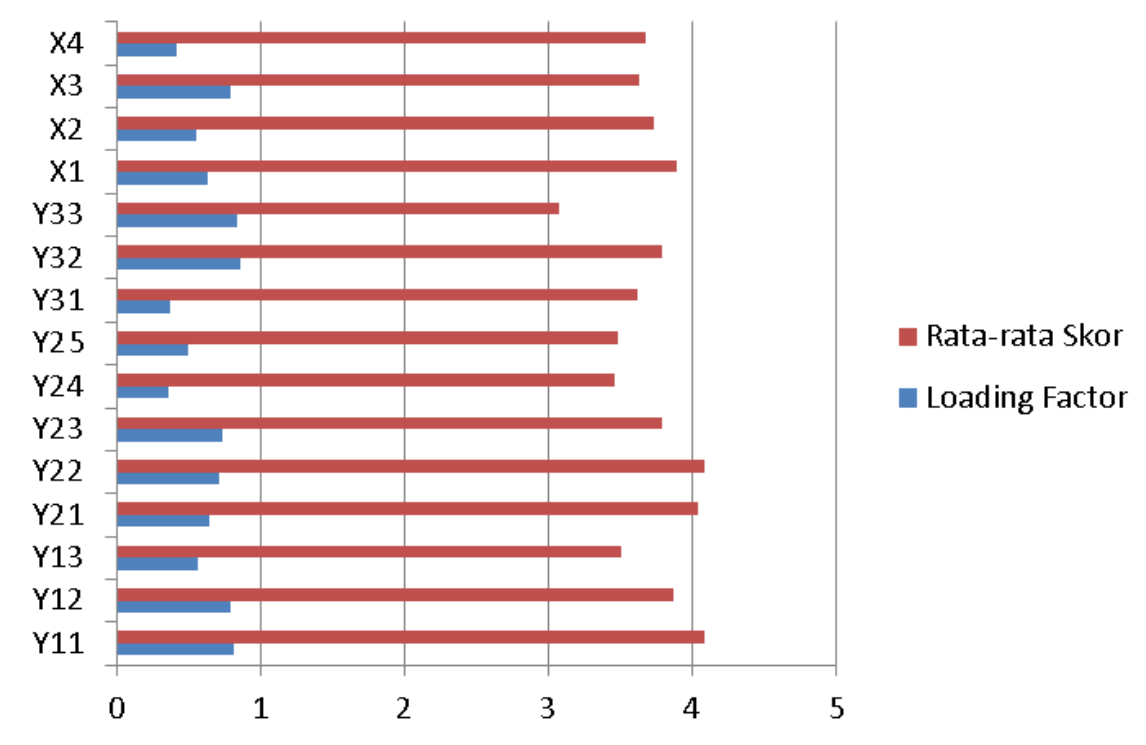

Gambar 5. Profil variable 


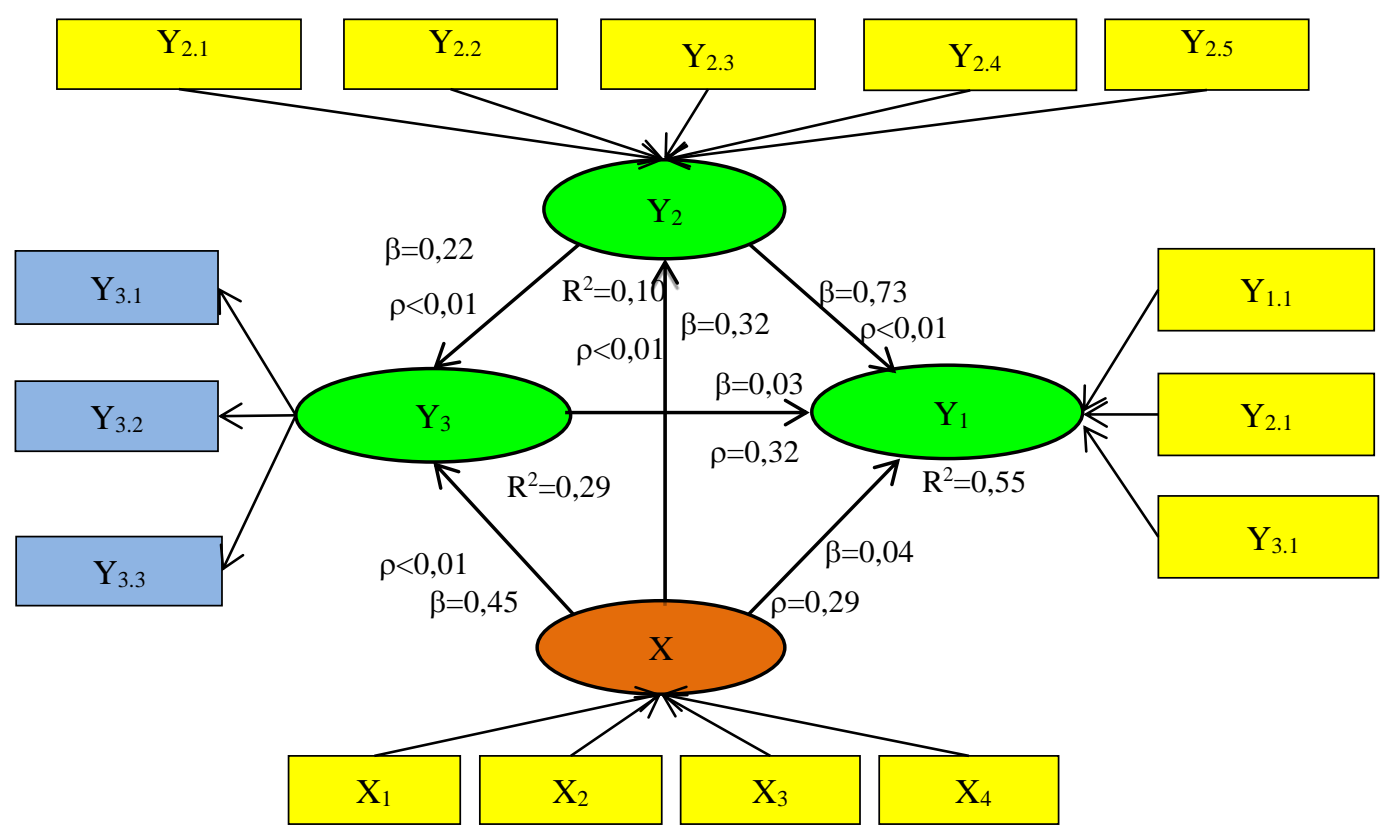

Gambar 6. Model SEM hasil analisis

Untuk mempertahankan keberlanjutan sistem irigasi Embung Haliwen dan Haekrit, maka diperlukan usaha pemeliharaan bangunan yang sistematis. Salah satunya adalah dengan mengidentifikasi faktor pengaruh, sehingga pengambilan keputusan tidak dilakukan tanpa dasar analisis. Pendekatan dengan menggunakan persamaam struktural, dapat dilihat secara jelas bagaimana pengaruh dari masing-masing variabel yang diuji terhadap penentuan jenis pemeliharaan dan hubungan antar variabel.

Dari analisa di atas menunjukkan bahwa stabilitas struktur bangunan embung $\left(\mathrm{Y}_{1}\right)$ berpengaruh secara langsung terhadap pemeliharaan embung irigasi. Indikator-indikator yang membentuk variabel stabilitas struktur memberikan kontribusi yang sangat signifikan dalan rangka perencanaan pemeliharaan embung irigasi. Hal ini berarti setiap terjadi perubahan pada komponen struktur embung seperti tubuh bendungan, kolam embung, spillway, jaringan distribusi dan bangunan bantu akan mempengaruhi penentuan jenis pemeliharaan embung. Untuk itu dapat dikatakan bahwa semakin menurun kondisi berbagai komponen struktur embung maka perlu diikuti dengan tindakan pemeliharaan embung yang sesuai dengan kondisinya.

Namun demikian, perubahan pada struktur embung dapat dipengaruhi juga oleh aspek fisik dan lingkungan (X). Hal ini terlihat dari pengaruh yang sangat signifikan dari aspek fisik dan lingkungan terhadap stabilitas struktur. Pengaruh yang kuat ini menunjukkan bahwa perubahan yang terjadi pada indikator-indikator yang membentuk variabel fisik dan lingkungan menyebabkan perubahan pula pada stabilitas struktur. Misalnya indikator perubahan bentangan alam, memiliki bobot di atas 3,5 dengan loading factor di atas 0,5 menunjukkan semakin kuat indikator tersebut dalam variabel fisik dan lingkungan yang berpengaruh langsung terhadap stabilitas struktur. Demikian pula untuk indikator lainnya dalam variabel fisik dan lingkungan, memiliki rata-rata skor di atas 3,5 dan loading factor di atas 0,5. Untuk itu sangat diperlukan pengendalian terhadap aspek fisik dan lingkungan sekitar embung guna menghindari terjadinya kegagalan struktur embung.

Akan tetapi, model yang dihasilkan ini juga menunjukkan tidak ada pengaruh yang signifikan variabel fisik dan lingkungan terhadap pemeliharaan embung. Dengan demikian maka variabel stabilitas struktur yang di dalam model dipandang sebagai variabel moderasi berubah menjadi variabel penjelas yang berarti bahwa pemeliharaan embung ditentukan berdasarkan variabel stabilitas struktur.

Selanjutnya, hasil analisis juga memperlihatkan hubungan yang signifikan antara variabel stabilitas struktur dan variabel fisik \& lingkungan dengan ekonomi. Hasil analisis ini menunjukkan indikator yang ada dalam variabel ekonomi (hasil pertanian, nilai manfaat, dana investasi) akan berubah jika stabilitas struktur dan aspek lingkungan mengalami perubahan. Hal ini dapat dipahami bahwa jika kondisi embung dalam keadaan stabil cenderung dapat meningkatkan hasil pertanian dan nilai manfaat sedangkan dana investasi akan sensitif juga terhadap perubahan dalam stabilitas struktur. 
Struktur yang stabil dapat mengurangi biaya investasi untuk pemeliharaan, demikian juga sebaliknya.

Akan tetapi, perubahan pada variabel ekonomi/finansial tersebut tidak siginifikan berpengaruh pada penentuan jenis pemeliharaan embung. Temuan ini menunjukkan bahwa tinggi rendahnya hasil pertanian, nilai manfaat embung dan besarnya dana investasi yang tersedia, tidak langsung berpengaruh pada penentuan jenis pemeliharaan embung irigasi.

Untuk itu, kepada pihak-pihak yang terlibat dalam pengelolaan Embung Haekrit dan Haliwen, perlu sekali mempertimbangkan tidak hanya aspek stabilitas struktur tetapi juga aspek fisik dan lingkungan dalam pemeliharaan embung. Kondisi fisik dan lingkungan sekitar embung harus tetap terjaga secara baik sehingga tidak memberikan permasalahan serius bagi stabilitas struktur. Dengan demikian dapat diperoleh pemeliharaan embung yang optimal yang mengintegrasikan berbagai aspek sehingga keberlanjutan sistem irigasi dapat terus dijaga.

\section{Kesimpulan}

Dalam melaksanakan program pemeliharaan embung irigasi, perlu kiranya dikembangkan berbagai alternatif solusi untuk mendapatkan hasil yang optimal. Dengan menetapkan kriteria-kriteria tertentu dan mengukurnya secara lebih menyeluruh akan membantu dalam pengambilan keputusan, khususnya dalam pengelolaan irigasi. Dari penelitian ini temuan yang diperoleh bahwa dalam pemeliharaan embung, aspek struktur bangunan embung merupakan tolok ukur dalam penentuan jenis pemeliharaan. Selain itu, aspek fisik dan lingkungan sekitar embung juga memiliki pengaruh yang kuat terhadap kualitas bangunan struktur embung.

Dari korelasi antara variabel stabilitas struktur dan variabel fisik dan lingkungan dengan ekonomi/finansial yang signifikan berpegaruh, menunjukkan perubahan atas kondisi struktur bangunan embung dan lingkungan sekitar embung akan berdampak pada besarnya biaya yang akan digunakan untuk investasi perbaikan atau pemeliharaan. Oleh karena itu, studi-studi mendatang diharapkan dapat melihat secara lebih detail, bagaimana pengaruh kondisi struktur bangunan, penentuan jenis pemeliharaan dengan dana investasi dan manfaat yang diperoleh. Selain itu juga perlu diselidiki lebih jauh pengaruh perubahan fisik bentangan alam maupun perubahan iklim terhadap aspek struktur embung. Dengan demikian dapat diperoleh suatu model yang lebih komprehensif menggambarkan pemeliharaan embung irigasi.

\section{Ucapan Terimakasih}

Ucapan terima kasih peneliti disampaikan kepada Direktorat Jenderal Penguatan Riset dan Pengembangan, Kementerian Riset, Teknologi dan Pendidikan Tinggi Republik Indonesia atas kepercayaannya memberikan dana hibah Penelitian Strategis Nasional serta Politeknik Negeri Kupang atas semua dukungannya. Terima kasih juga kepada BWS NT II, Dinas PU \& Tata Ruang Kabupaten Belu dan masyarakat petani pemakai air di Haliwen dan Haekrit atas kerjasamanya.

\section{Daftar Pustaka}

Amin, M, Wibowo, MA \& Atmojo. (2016). Pengaruh Penerapan Sistem Manajemen Mutu terhadap Kualitas Pelaksanaan Kegiatan Operasi dan Pemeliharaan (Studi Kasus: Tugas Pembantuan Operasi dan Pemeliharaan Daerah Irigasi Kedung Asem dan Daerah Irigasi Bodri Provinsi Jawa Tengah). Jurnal Media Komunikasi Teknik Sipil, 22(1), 1-12. Retrieved from https://ejournal .undip.ac.id/index.php/mkts/article/download/1240 $1 / 10239$

Anjasmoro, B., Suharyanto \& Sangkawati, S. (2015). Analisis Prioritas Pembangunan Embung Metode Cluster Analysis, AHP dan Weighted Average (Studi Kasus: Embung di Kabupaten Semarang). Jurnal Media Komunikasi Teknik Sipil, 21(2), 101-112. Retrieved from https://ejournal. undip.ac.id/index.php/mkts/issue/view/1757

Balai Wilayah Sungai N. T II. (2015). Data Embung. Kupang.

Bria, M, Muda, AH \& Sutirto. (2017). Analisis Kriteria untuk Perencanaan Program Pemeliharaan Embung Irigasi (Studi Kasus: Embung Haliwen dan Haekrit Kabupaten Belu). Jurnal Teknik Sipil dan Perencanaan, 19(2), 83-89. Retrieved from https://journal.unnes.ac.id/nju/index.php/jtsp/articl e/download/11112/7000\%0A\%0A

Direktorat Jenderal Prasarana dan Sarana Pertanian. (2019). Pedoman teknis Pengembangan Embung Pertanian Direktorat Irigasi Pertanian. Retrieved from

http://psp.pertanian.go.id/assets/file/2019/Pedoman _Teknis_Pengembangan_Embung_2019.pdf

Haribowo, I. (2017). Pengaruh Pengumuman Likuidasi Bank terhadap Minat Menarik Uang dari Bank. Modus, 29(1), 17-35. Retrieved from https://ojs.uajy.ac.id/index.php/modus/article/view 
/1037

Hermantoro. (2011). Peningkatan Efektifitas Tampungan Embung melalui Perbaikan Bentuk dan Dimensi. Buletin Geologi Tata Lingkungan, 21(1), 35-41. Retrieved from www.bgl.esdm.go.id/ publication/index.php/dir/article_download/573\%0 $\mathrm{A} \% 0 \mathrm{~A}$

Heryant, LY, Sobriya \& Suprapto, M. (2014). Pengembangan Penilaian Kondisi Fisik Bendungan untuk Penentun Penanganan Pemeliharaan Bendungan (Study Kasus: Waduk Lodan). Jurnal Teknik Sipil Magister Teknik Sipil Universitas Sebelas Maret, II(1), 89-99. Retrieved from jurnal.ft.uns.ac.id/index.php/s2sipil

Joubert, M. D. \& Prihantoko, A. (2015). Analisis Keberterimaan Pengguna terhadap Aplikasi Sistem Manajemen Operasi Irigasi Menggunakan Technology Acceptance Model (Studi Kasus Daerah Irigasi Boro, Purworejo). Jurnal Irigasi, 10(1), 11-20. Retrieved from http://jurnalirigasi_ pusair.pu.go.id/index.php/jurnal_irigasi/article/vie $\mathrm{w} / 31$

Kock, N. (2019). Factor-Based Structural Equation Modeling with WarpPLS. Australasian Marketing Journal. Retrieved from https://doi.org/doi. org/10.1016/j.ausmj.2018.12.002

Meluk, Y., Suprapto, M., Syafi'i. (2015). Penyusunan Skala Prioritas Program Rehabilitasi Embung Kecil di Kabupaten Kupang Provinsi NTT. Jurnal Teknik Sipil, III(1). Retrieved from https://jurnal.ft.uns.ac.id/index.php/s2sipil

Mufute, N. (2007). The Development of a Risk-ofFailure Evaluation Tool for Small Dams in Mzingwane Catchment (University of Zimbabwe). Retrieved from http://citeseerx.ist.psu.edu /viewdoc/download?doi=10.1.1.900.2461\&rep=re p1\&type $=$ pdf

Mulyadi, Soekarno, I \& Natasaputra, S. (2014). Penilaian Kinerja Irigasi Berdasarkan Pendekatan Permen PU No.32/2007 dan Metode Masscote dengan Evaluasi Rapid Appraisal Procedure (RAP) di Daerah Irigasi Barugbug - Jawa Barat. Jurnal Irigasi, 9(2), 126-135. Retrieved from http://jurnalirigasi_pusair.pu.go.id/index.php/jurna 1_irigasi/article/download/53/57

Nugroho, H \& Suripin. (2013). Penatagunaan Kawasan Sekitar Waduk dalam Upaya Menjaga
Kelestariannya (Model DAM). Jurnal Media Komunikasi Teknik Sipil, 19(2), 109-124. Retrieved from https://ejournal.undip.ac.id/index.php/ mkts/article/view/8420

Nyoni, K. (2013). Environmental Impacts of Earth Dam Failures and Spillway Malfunctions. Greener Journal of Physical Sciences, 3(5), 177-186. Retrieved from http://www.rainwatertechcentres .net/images/PDF/Nyoni_2013_Earth_dams.pdf\%0 A

Peraturan Menteri Pekerjaan Umum. Pedoman Penyelenggaraan Pemeliharaan Jaringan Irigasi. , Pub. L. No. 12 (2015).

Sayekti, RW, Soetopo, W \& Agisaqma, L. (2012). Penentuan Kinerja Irigasi pada 16 Bangunan Utama (Secara Seri) di Daerah Irigasi Jilu, Kabupaten Malang. Jurnal Teknik Pengairan Universitas Brawijaya, 3(1), 33-38. Retrieved from https://jurnalpengairan.ub.ac.id/index.php/jtp/articl e/view/144/142

Solimun, M. S., Fernandes, A. A. R. \& Nurjanah. (2017). Metode Statistika Multivariat, Pemodelan Persamaan Struktural (SEM) - Pendekatan WarPLS. Malang: UB Press.

Umaru, A., Ogedengbe, K., \& Omobowale, M. O. (2010). Structural Failures of Earth Dams in Nigeria: A Case Study of Cham Dam in Gombe State. Journal of Engineering and Applied Sciences, 5(11), 47-52. Retrieved from www.arpnjournals.com/jeas/.../rp_2010/jeas_1110 _412.pdf\%0A

Wibowo, R. S., Wardoyo, W., \& Edijatno. (2018). Strategi Pemeliharaan Jaringan Irigasi Daerah Irigasi Blimbing. Jurnal Aplikasi Teknik Sipil, 16(1), 23-30. Retrieved from http://iptek.its.ac.id/index.php/jats/article/view/279 3

Widiyono, W. (2011). Profil "Embung" dan Sumberdaya Air di Wilayah Perbatasan Kabupaten Belu - NTT, Seminar Nasional Bilogi, 164-170. Retrieved from https://jurnal.fkip.uns.ac.id/ index.php/prosbio/article/view/885/543

Wieland, M. (2016). Safety Aspects of Sustainable Storage Dams and Earthquake Safety of Existing Dams. Engineering, 2(2016), 325-331. Retrieved from https://doi.org/http://dx.doi.org/10.1016/ J.ENG.2016.03.011 